\title{
New Snow-Physics to Complement SSiB
}

\section{Part II: Effects on Soil Moisture Initialization and Simulated Surface Fluxes, Precipitation and Hydrology of GEOS II GCM}

\author{
By David M. Mocko, ${ }^{1}$ Greg K. Walker ${ }^{1}$ and Y.C. Sud \\ Laboratory for Atmospheres, NASA/Goddard Space Flight Center, Greenbelt, MD 20771, U.S.A.
}

(Manuscript received 28 February 1998, in revised form 4 January 1999)

\begin{abstract}
The SSiB model, which was forced with GSWP ISLSCP Initiative I surface data, was modified to include more realistic snow physics and snow-melt infiltration. The new snow model in SSiB was again integrated with the GSWP data. The new SSiB simulation produced wetter and warmer soil, with more realistic snow-melt timing and runoff, in regions of significant snow-melt. The simulation was used for initializing land-surface temperature, soil moisture, and snow cover for the GEOS II GCM, which was integrated for JJA to generate an ensemble of runs for both 1987 and 1988. Each ensemble contained six cases starting from an ECMWF analysis for each day starting from 29 May through 3 June of each year.

As compared to the old SSiB GCM, the new SSiB GCM with new initial hydrologic conditions significantly improved the prediction of precipitation in mid-to-high-latitude regions of Canada and Russia. Evapotranspiration, soil moisture, and runoff also compared more favorably in the new SSiB GCM simulation than the old SSiB GCM. Also, the 1988-1987 difference in northern India precipitation was more pronounced in the new SSiB GCM. In the U.S., where the old SSiB GCM had failed to simulate the 1988 drought circulation, the new SSiB GCM performed only slightly better. This was also evident in the 19881987 differences. In this region, the influence of initial conditions was mostly lost in about one month's time to the evolution of an unrealistic circulation.
\end{abstract}

\section{Introduction}

One of the key factors in simulating accurate landhydrology in a general circulation model (GCM) is realistic initial soil moisture (ISM). Precipitation records, while still not entirely satisfactory, are available for most land regions (e.g., Xie and Arkin 1995; Huffman et al., 1997; Schneider 1993). However, corresponding soil moisture records are far more limited in both space and time coverage. The best available records exist for the Russian Wheat Belt Region across central Russia (Vinnikov and Yeserkepova, 1991), and for other isolated regions such as in Illinois (Hollinger and Isard, 1994) in the U.S. and in China and India. Consequently, researchers have turned to alternative methods for estimating soil

Corresponding author: David M. Mocko, Laboratory for Atmospheres, NASA/Goddard Space Flight Center, Greenbelt, MD 20771, U.S.A. E-mail: mocko@climate. gsfc.nasa.gov, URL: http://climate.gsfc.nasa.gov/ $\sim$ mocko/

1 Additional affiliation: General Sciences Corporation, Beltsville MD, U.S.A.

(C) 1999 , Meteorological Society of Japan moisture. Manabe (1969) produced a global field of soil moisture, following the work of Budyko (1956), for a version of the GFDL GCM. Mintz and Serafini (1984) produced a climatology of global fields of soil moisture by integrating a water budget equation, using observed precipitation and estimated evapotranspiration (as a function of potential evapotranspiration and soil moisture) together with a simple runoff equation. These fields were used as boundary conditions of soil moisture in several GCMs for quite some time. Mintz and Walker (1993) further improved the soil moisture calculation by using a revised formulation of the moisture availability parameter.

Modern GCMs also have more explicitly simulated evapotranspiration by including advanced surface biosphere models such as SSiB (Xue et al., 1991), among others. Mocko and Sud (1998) compared soil moisture produced by three popularly used potential evapotranspiration parameterizations to that produced by $\mathrm{SSiB}$ using ISLSCP Initiative I data (IIIData). Garratt (1993) reported on the sensitivity of climate in GCMs to the treatment of the 
land-surface interaction, while Betts et al. (1997) detailed this effect within the operational version of the Eta Model. Most recently, Dirmeyer (1999, this volume) has shown that the COLA GCM, which uses the COLA version of SSiB, produced a more skillful climate prediction if the soil moisture is initialized with IIIData. Dirmeyer's study reaffirms the inherent value of realistic soil moisture initialization. Sensitivity of local hydrology and precipitation to the ISM has been studied in both short-to-mediumrange atmospheric models (e.g., Miyakoda et al., 1979; Yang et al., 1994; Beljaars et al., 1996) and in seasonal and climate simulations (e.g., Mintz, 1984; Sud and Fennessy (1984); Sud and Smith (1985); Sud and Molod (1988); Atlas et al., 1993). However, the dependence of precipitation on soil moisture is difficult to discern, as opposed to its converse, which is straightforward. Delineation of a soil moistureprecipitation relationship from observations and/or models is a difficult task, particularly because the influence of the annual cycle and the effects of interannual variability of precipitation can be much stronger. Nevertheless, GCMs are valuable tools for addressing such problems, but their major limitations are due to the known deficiencies, simplifying assumptions, and systematic errors in physical parameterizations.

With the advent of the Global Soil Wetness Project (GSWP), and its use of IIIData (Meeson et al., 1995; Sellers et al., 1995) as a best estimate of surface observations, the SSiB model was integrated to yield hourly surface fluxes, soil moistures, and ground temperatures over the globe for a two-year period, 1987-1988. Mocko and Sud (1998) provide a summary of several successes of the SSiB integration, as well its failings, especially in areas with large snow-melt infiltration. Sud and Mocko (1999) resolve this by constructing a new snow model that was developed and tested with the IIIData. The new simulation revealed marked improvements in snow-melt timing and infiltration, lateral runoff, soil moisture, and evapotranspiration, particularly in the summer following the spring season.

In this study the GEOS II GCM, with ISM produced by $\mathrm{SSiB}$ in its two versions with the new and old snow model, is used to determine if the new snow model can make a difference in regional circulation and precipitation, and whether this difference can yield a significant and observationally verifiable improvement on the climate forecast. Section 2 reports on some of the improvements in the new snow model over the old snow model in $\mathrm{SSiB}$, along with the difference in the initial conditions produced by them. Section 3 describes the GEOS II GCM coupled to the new snow model SSiB and the simulations. Section 4 provides the results and Section 5 offers the summary and conclusions.

\section{New snow model and SSiB}

The SSiB model has previously been noted to have a problem producing accurate soil moisture as compared to observations in the Russian snow-melt region (Robock et al., 1995; Xue et al., 1997). In the recent GEWEX (Global Energy and Water Cycle Experiment) GSWP exercise, the Russian soil moisture deficiency again emerged as a persistent problem. It was noted that various implementations of $\mathrm{SiB}$ (often called SiBlings; other versions exist at COLA and JMA) were unable to simulate the annual cycle of the Russian soil moisture. The spring rise in soil moisture due to the infiltration of snowmelt was largely missing, while the runoff was huge (nil) in the spring (winter) as compared to observations. Earlier, Mocko and Sud (1998) also found the Russian soil moisture simulated was more realistic in models that did not have ground temperature or sophisticated snow-melt infiltration, clearly suggesting a deficiency in the snow-melt infiltration parameterization.

Consequently, a new snow model was written for use in SSiB. Its major components include a new predictive equation for snow temperature and the separation of heat capacities for both snow and ground. In the design, the snow/ice cover acts as an insulating and shortwave transmission medium. The surface fluxes of evapotranspiration, sensible heat, and outgoing longwave radiation are balanced at the top of the snowpack. Downward shortwave energy is absorbed as well as transmitted through the snow. Heat is transported between the snow cover and ground by conduction through both soil and snow cover and by longwave radiation through the air gap between the soil and snow cover. Also, snowmelt can refreeze on the ground and further warm the frozen ground by release of latent heat. More details about the new snow model can be found in Sud and Mocko (1999), this volume.

The SSiB model was integrated again starting with a ten-year spin-up as done by GSWP, but using the new snow model. Highlights of the results of the new model are: (i) snow-melt occurred earlier in most regions and closer to observations from satellite (Fig. 1a); (ii) ground temperature did not go into a deep winter freeze if the snow pack was deep; (iii) winter surface fluxes were reduced as calculated over freezing temperatures; (iv) the ground thawed several weeks earlier; (v) snow-melt infiltrated into the soil as a result of the warmer ground through the winter and as a result of refreeze, (vi) soil moisture was higher year-round in mid-to-high latitude regions, but especially in the spring after snow-melt; (vii) evapotranspiration was higher during the summer as a result of wetter soil; and, (viii) runoff was reduced in spring, but higher runoff (especially baseflow) was produced in the winter. In 


\section{Old SSiB Snowmelt Error in Weeks}

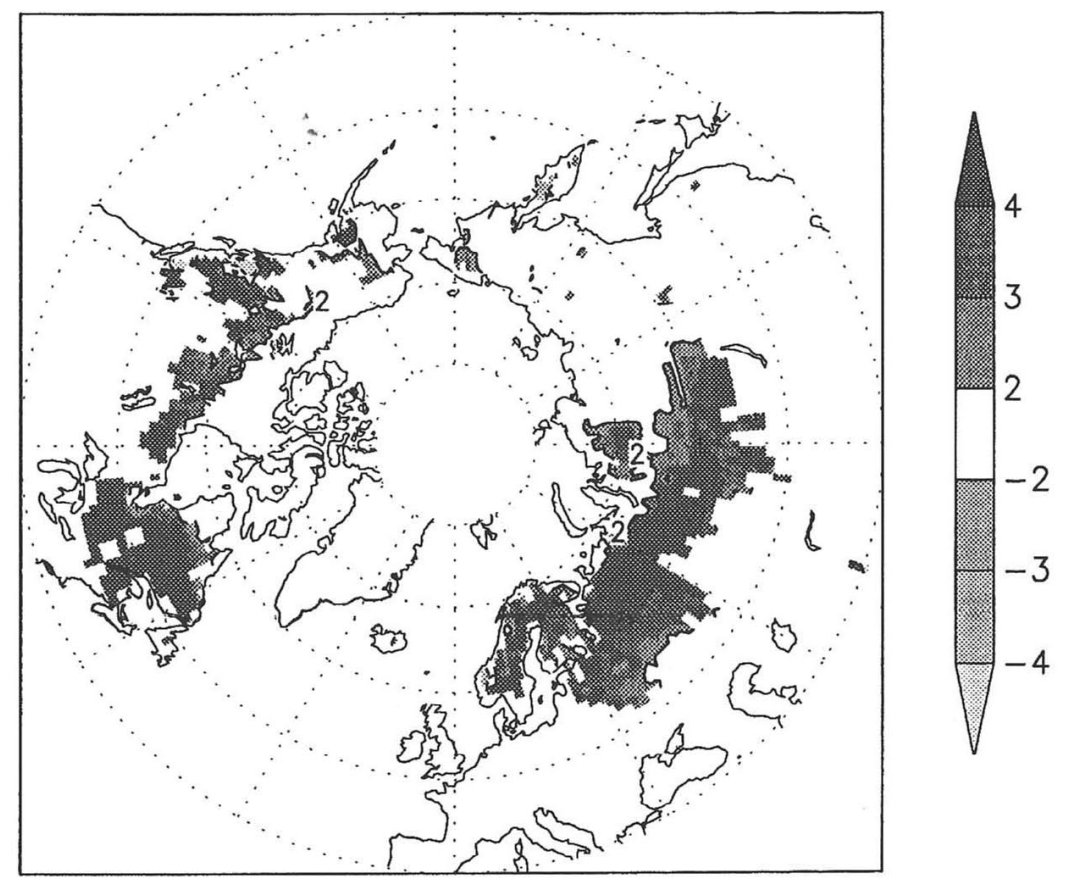

\section{New SSiB Snowmelt Error in Weeks}

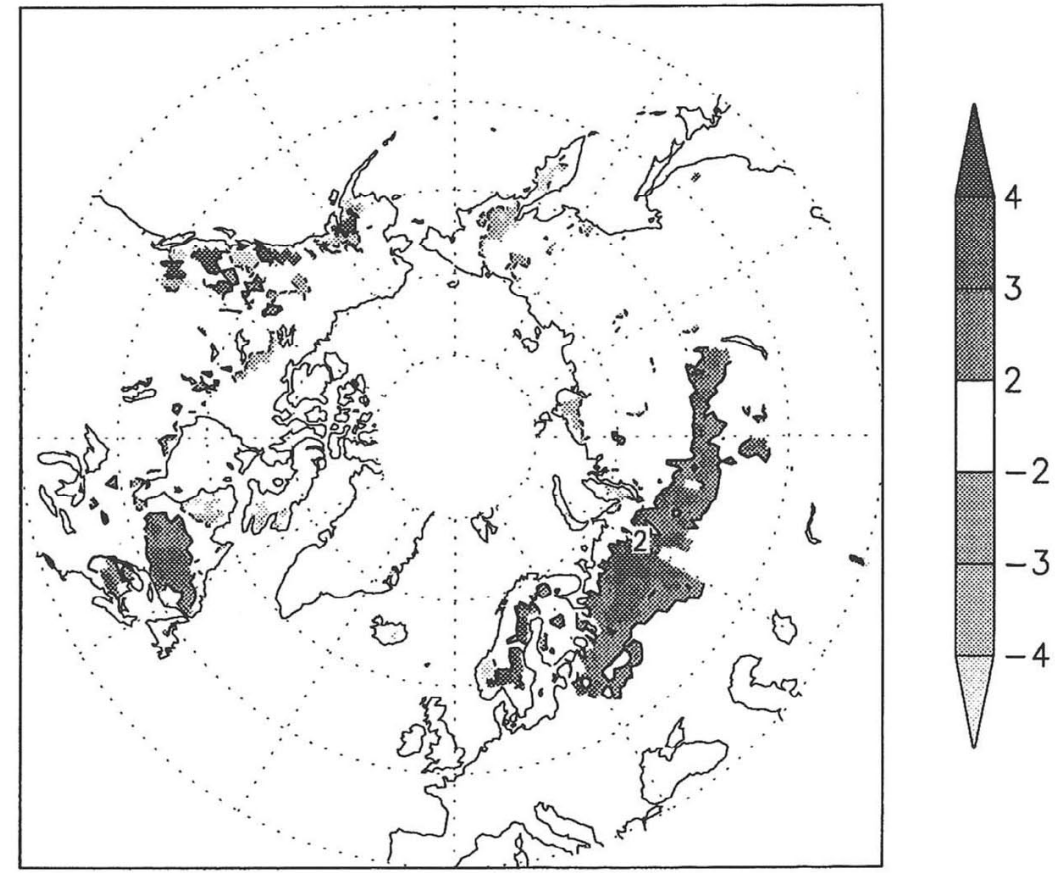

Fig. 1a. Snowmelt error (in weeks) compared to observations from satellites in both the old (top), and new (bottom) snow models in SSiB. Only points with a peak of $100-\mathrm{mm}$ in snow cover during the winter are shown.

a region of northeast Russia, the new $\mathrm{SSiB}$ model simulated soil moisture and runoff much closer to observations than the original SSiB model.

Differences in the 1 June ground temperature and root zone soil wetness between the old and new snow model in SSiB are shown in Fig. 1b. Only the Northern Hemisphere is shown, because the significant differences were found in high snow accumulation 


\section{Ground Temperature Difference (C)}

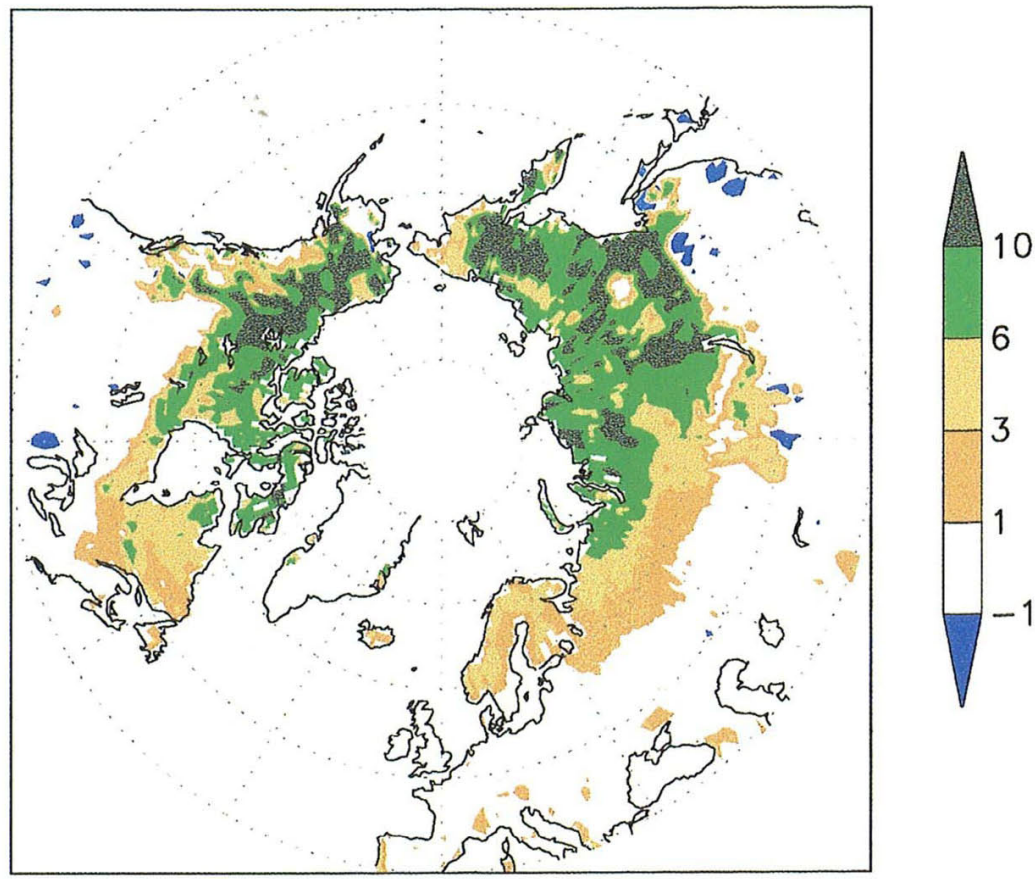

\section{Root Zone Wetness Difference $(0-1)$}

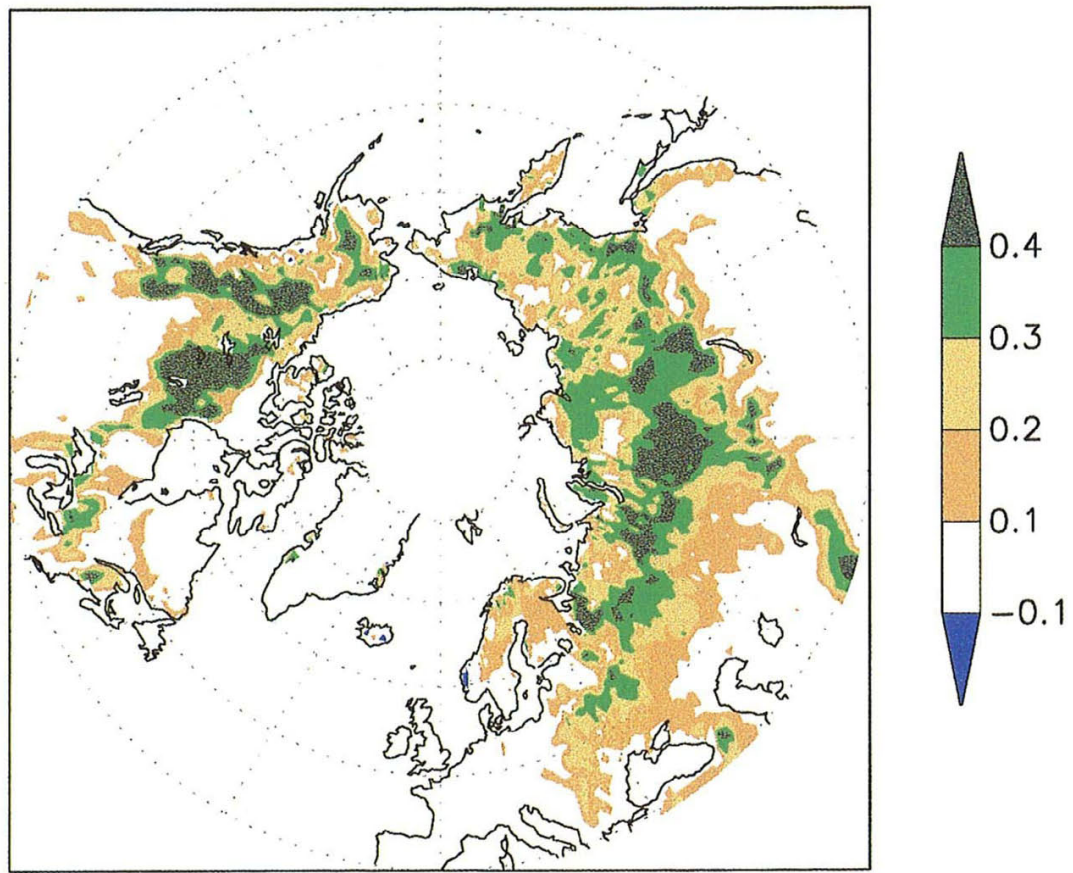

Fig. 1b. Difference in 1 June conditions for new versus old snow model in SSiB. Ground temperature difference (top) is in degrees C; dimensionless soil wetness in the root zone (bottom) is in the range $(0-1)$.

and snow-melt infiltration areas. As can be seen, the ground temperatures in the new snow model are much warmer in the mid-to-high latitudes, thus allowing additional snow-melt infiltration, which leads to wetter soil in the new snow model in northern Canada, central Russia, and even into the Himalayas. The effect of the new snow model on deep soil wetness and temperatures (not shown) are sim- 
Table 1. Detail of GCM experiment initial conditions and model setup. Each of the simulations in the table is actually an ensemble of six GCM start dates (29 May through 3 June). All simulations were integrated over JJA.

\begin{tabular}{clc}
\hline Simulation & \multicolumn{1}{c}{ Initialization Data } & GCM type \\
\hline $\mathrm{A}$ & 1 June 1987 New SSiB & NSGSM 1987 \\
$\mathrm{B}$ & 1 June 1987 Old SSiB & OSGCM 1987 \\
$\mathrm{C}$ & 1 June 1988 New SSiB & NSGCM 1988 \\
$\mathrm{D}$ & 1 June 1988 Old SSiB & OSGCM 1988 \\
$\mathrm{E}$ & 1 June 1987/1988 Average New SSiB & NSGCM 1987 \\
$\mathrm{F}$ & 1 June 1987/1988 Average New SSiB & NSGCM 1988 \\
\hline
\end{tabular}

ilar in both magnitude and extent. These 1 June values of soil wetnesses and temperatures serve as the initial values for the GCM simulations described in the next section.

\section{The GEOS GCM model and simulations}

The current $4^{\circ}$ lat. by $5^{\circ}$ long. 20-layer version of the GEOS II GCM was used in this investigation. The differences between this and the documented GEOS I GCM (Takacs et al., 1994) are additional features that invoke: (i) a gravity wave drag parameterization due to Zhou et al., (1996); (ii) SSiB of Xue et al., (1991); and, (iii) a new Microphysics of Clouds with relaxed Arakawa-Schubert Cumulus scheme (McRAS) by Sud and Walker (1998). The model also produces a realistic annual cycle of the global circulation, as well as realistic tropical and Indian Monsoon circulation and precipitation differences for 1987 (El Niño) minus 1988 (La Niña) summers. The model also produces a very reliable cloud-radiative forcing. Its 30-60 day oscillations over the equatorial tropical regions are quite robust, as was noted in the earlier GLA GCM (Lau and Yang, 1996).

The simulations consist of a six-ensemble set of six forecasts each. There are two summer periods, June-July-August (JJA), one for 1987 and one for 1988. The GCM was integrated to the end of August, using actual SSTs as provided in AMIP (Gates 1992; Lau et al., 1996). Using both the old and new snow model in SSiB gives four sets of ensemble simulations. Each simulation in the ensemble used the 1 June initial conditions of soil moisture, snow cover, and ground temperatures produced by the offline (driven with IIIData) SSiB with the new or old snow model as applicable. To determine the influence of ISM, two other ensembles were performed with the new snow model, using the average initial values from the new snow model $\mathrm{SSiB}$ on 1 June 1987 and 1 June 1988. To form an ensemble, each of six integrations is initialized from the ECMWFanalyzed atmospheric state on one of the following dates: 29 May through 3 June. The results from the six integrations over the three months are then averaged to give the ensemble values. These simulations and their corresponding initial conditions are detailed in Table 1.

The mid-to-high latitude Northern Hemisphere is a focus of this study because these regions receive a large amount of snowfall in the winter; the subsequent snow-melt in spring helps to recharge the soil moisture and generate runoff. This recharge is crucial for water availability to the biota and evapotranspiration into the following summer. The aim is to determine the influence of $\mathrm{SSiB}$ snow-model improvements on the verifiable climate forecasts.

\section{Simulation results}

4.1 Regional time series of surface fluxes, precipitation, and hydrology

Results for the six GCM simulations compared to the offline (forced with the IIIData) SSiB results with the new snow model are shown in this section. The six boxes around the shaded area in Fig. 2a through $2 \mathrm{c}$ are a time-series area average of the values within the box from 1 June to $31 \mathrm{Au}-$ gust. Each box has three lines, which represent 1) NSGCM (New SSiB GCM simulations, Simulations A and C); 2) OSGCM (Old SSiB GCM simulations, Simulations B and D); and, 3) the offline SSiB values produced with the new snow model. Observed precipitation is from the IIIData.

Figure 2a shows a remarkable change in the performance of NSGCM against OSGCM in northern Canada. The shaded area in the center of the figure shows that the ISM in the new SSiB is wetter than the old SSiB by an average wetness fraction of 0.2 . The precipitation in OSGCM is lower than the observations, while the precipitation in NSGCM is slightly higher than observed, in part due to evapotranspiration (hereafter, also referred to as evaporation) being larger than that produced from the offline SSiB. Correspondingly, evaporation (sensible heat) is significantly lower (higher) in OSGCM as compared to NSGCM. The net radiation calculated is similar in all GCM simulations, becoming slightly less than the offline $\mathrm{SSiB}$ by the end of the summer. The offline SSiB also shows the soil dry- 

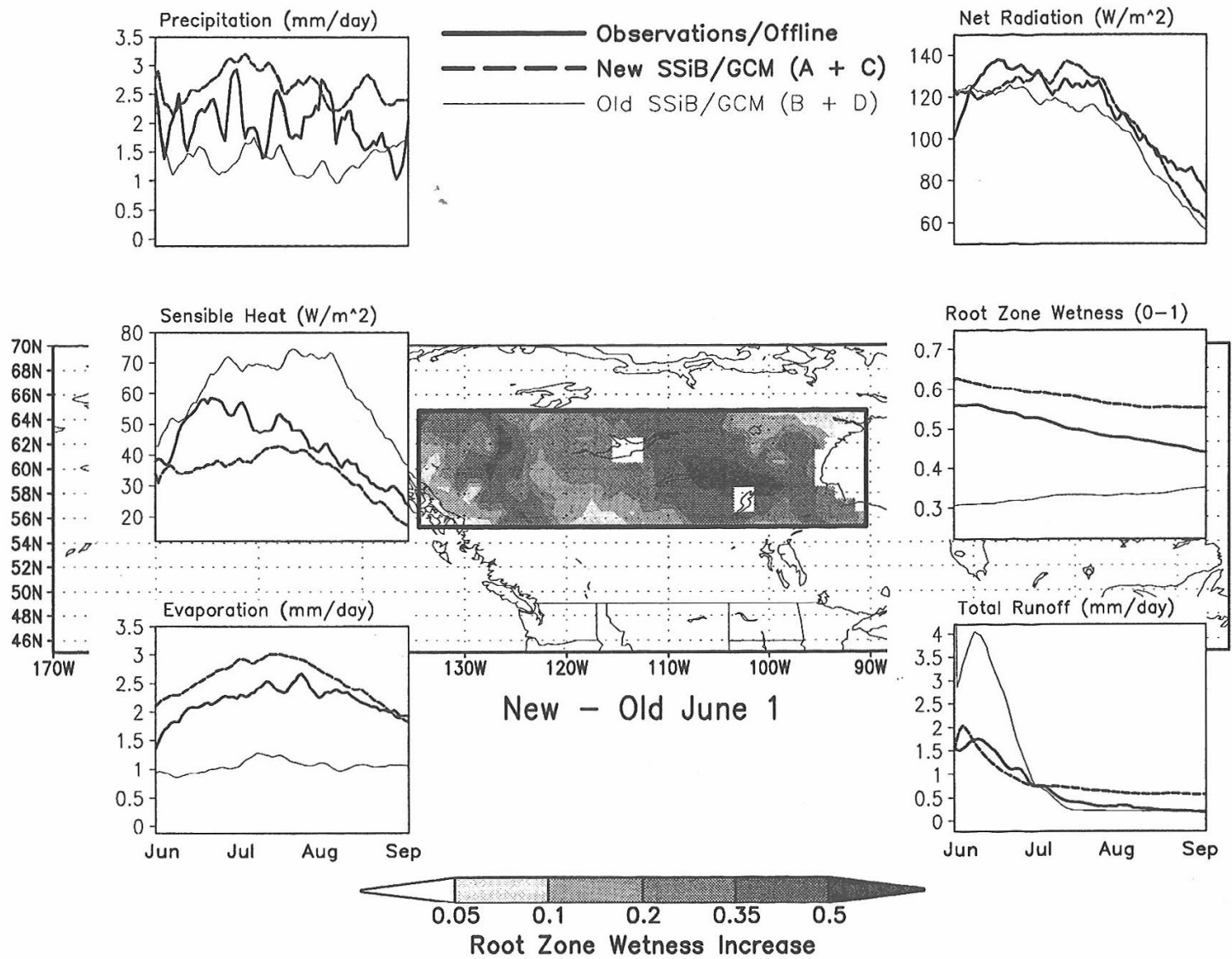

Fig. 2a. Two-year average of various fluxes and hydrology parameters for three sets of experiments in northern Canada: 1) offline SSiB/observations, 2) NSGCM (Simulations A and C), and, 3) OSGCM (Simulations B and D). Units and variable names are above the time-series plots, which are a five-day running mean of the area average within the box $(55-65 \mathrm{~N} ; 135-90 \mathrm{~W})$, from 1 June to 31 August. The shaded area in the center of the figure shows the difference in the new minus old snow model offline $\mathrm{SSiB} 1$ June initialization of root zone soil wetness.

ing on a shorter time scale during the summer than produced by NSGCM. Still, compared to OSGCM, NSGCM has a wetter soil similar to that found in the offline. Possibly the most remarkable improvement is in the runoff, which shows OSGCM producing much larger values than both NSGCM and the offline before July. This result is related to a delayed snow-melt and lack of snow-melt infiltration found in OSGCM.

Figure 2b shows that ISM is much wetter in the new than the old SSiB GSWP integration in central Russia. The NSGCM precipitation matches closely with the observed (especially in the midsummer), while OSGCM has too little precipitation. A wetter soil in this region has led to greater evaporation and precipitation. Sensible heat and evaporation in NSGCM are very close to that produced by the offline SSiB, while OSGCM compares poorly. Also in this region, the soil wetness decreases in NSGCM at a slower rate than found in the offline. The feedback of soil wetness into precipitation in the GCM is the likely cause, whereas in the offline, observed precipitation is used as forcing. Again, the runoff in
OSGCM is very high before July. Sud and Mocko (1999) showed that the offline new SSiB simulation produced more realistic runoff (and also soil water storage) as compared to observations in this region.

The effect of new ISM in the Great Plains region is shown in Fig. 2c. The new snow model does not produce as large an increase in ISM. It is argued that the 1987 and 1988 circulation anomalies in this region are more dominant than the soil wetness effect; NSGCM and OSGCM do equally poorly in simulating the circulation (not shown) and precipitation. Correspondingly, the GCM simulations produce more (less) sensible heat flux (evaporation) than that produced by the offline, while soil wetness dries much more rapidly in the GCM simulations. The net radiation simulated by the GCM is also much lower towards the end of summer, which may result from too much simulated cloudiness. The offline new SSiB simulation of soil moisture and runoff in this region were favorably compared to observations by Mocko and Sud (1998).

Figures $3 \mathrm{a}$ through $3 \mathrm{c}$ depict time series of various fields for 1988-1987 difference for the regions. 

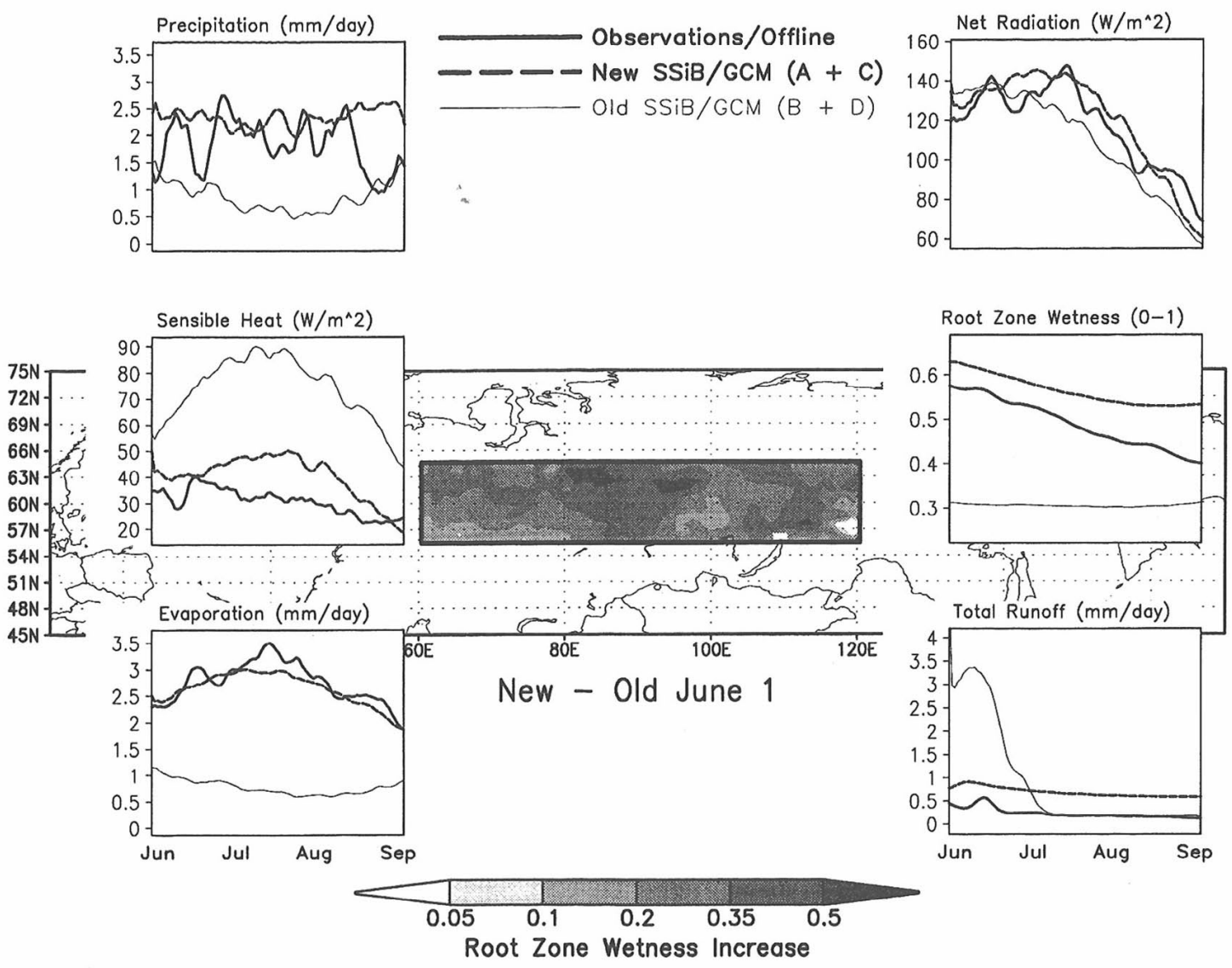

Fig. 2b. Same as Fig. 2a, only for Russia (55-65N; 60-120E).

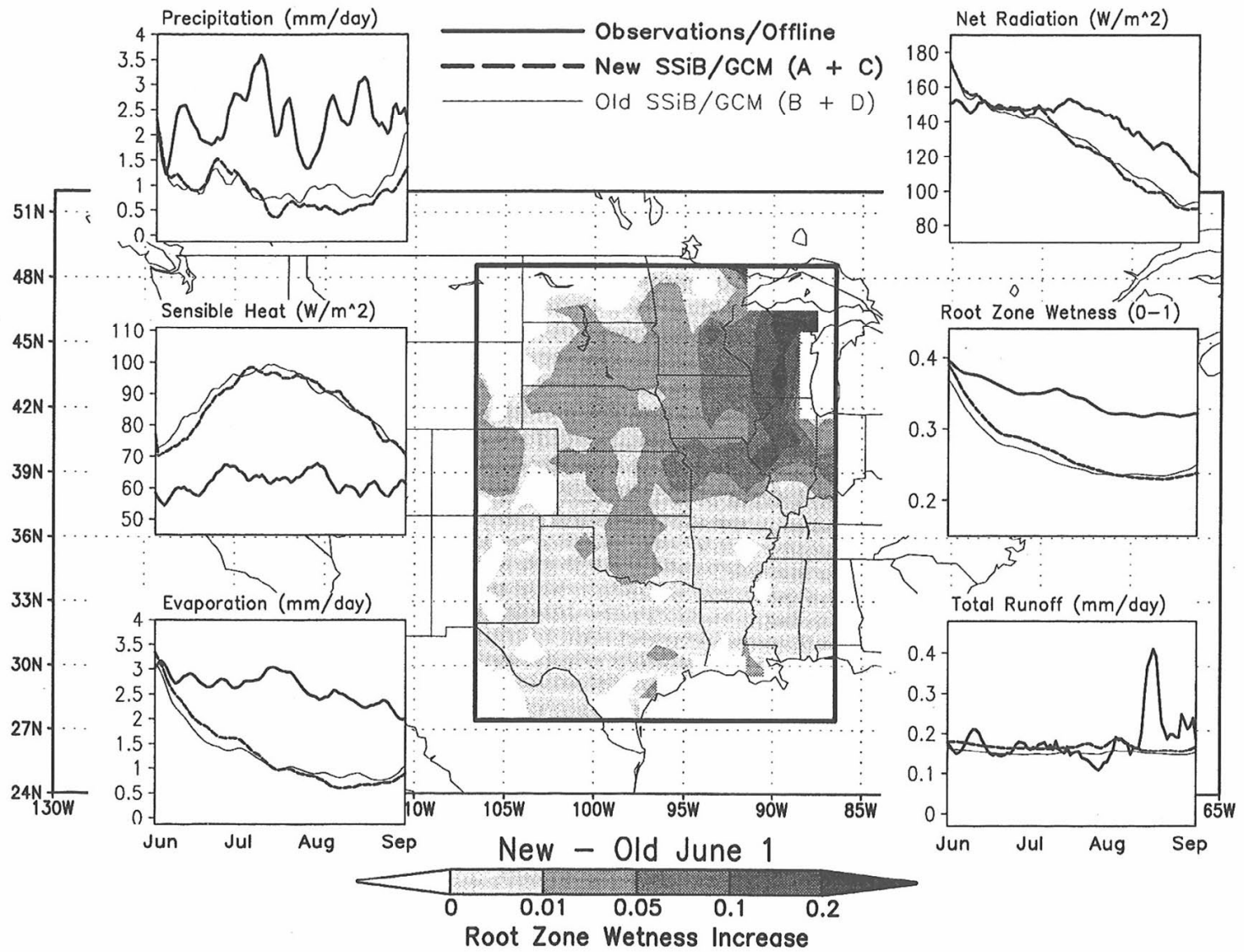

Fig. 2c. Same as Fig. 2a, only for the U.S. (27-49 N; 107-86W). 

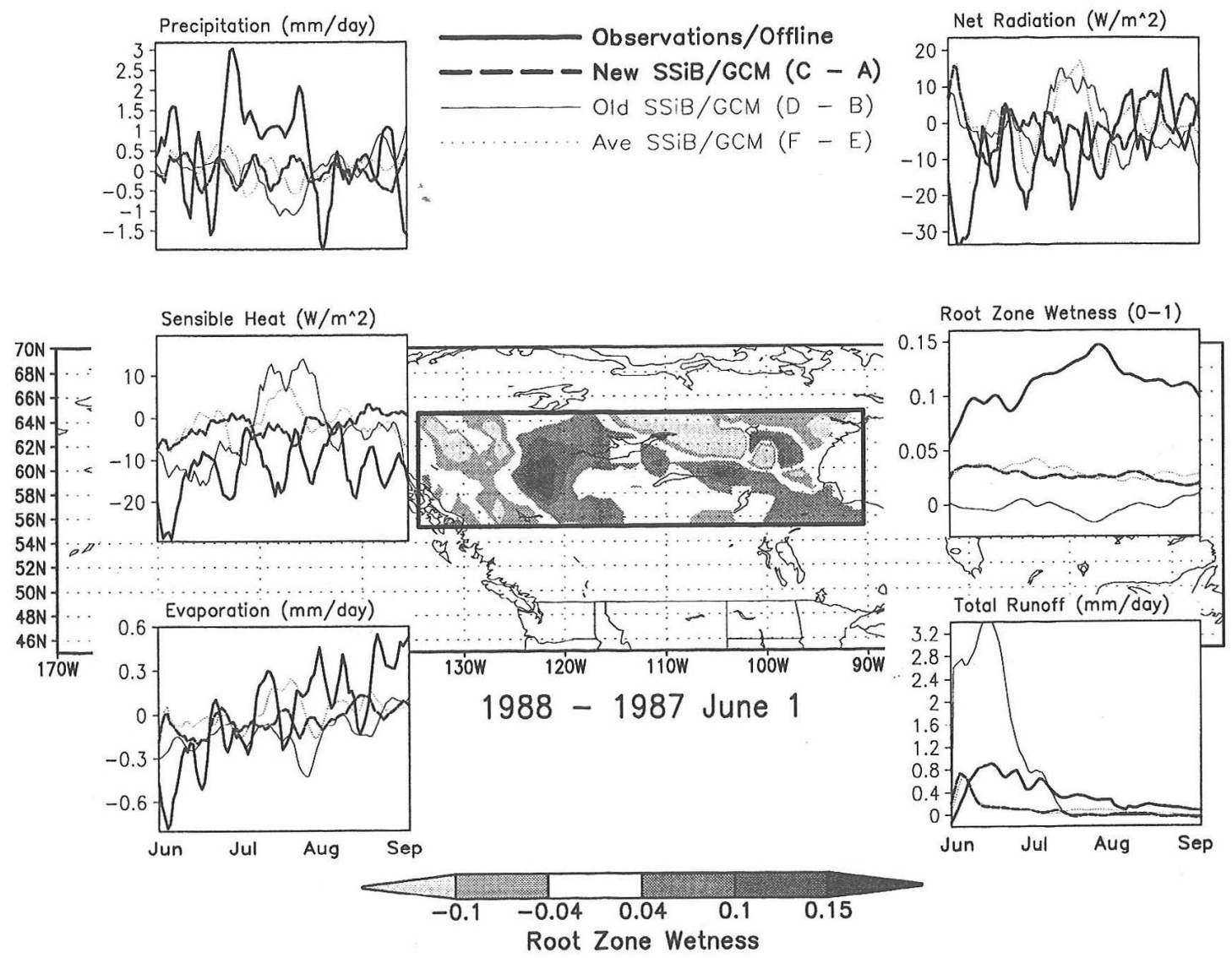

Fig. 3a. 1988-1987 Difference in various fluxes and hydrology parameters for four sets of experiments in northern Canada: 1) offline SSiB/observations, 2) NSGCM (Simulations C-A), 3) OSGCM (Simulations D-B), and, 4) EFxpts (Simulations F-E). Units and variable names are above the time-series plot, which is a five-day running mean of the area average within the box $(55-65 \mathrm{~N} ; 135-90 \mathrm{~W})$, from 1 June to 31 August. The shaded area in the center of the figure shows the difference in the 1988 minus 1987 offline SSiB 1 June initialization of root zone soil wetness.

The same three set of simulations are shown as before, plus a new set named EFxpts (Average ISM New SSiB GCM simulations, Simulations E and F). In northern Canada (Fig. 3a), some regions of ISM are wetter in 1987 and some are wetter in 1988. The time series in annual differences of precipitation, sensible heat, and evaporation are very variable and show no real trend. In the offline soil wetness, the general trend is wetter in 1988 than in 1987, and this is better reflected in NSGCM, while OSGCM shows no difference. Also, the runoff is again much higher in 1988 in OSGCM, due to the effect of delayed snow-melt and infiltration. In Russia (Fig. 3b), there is no strong interannual trend in any variable other than soil wetness, which NSGCM improves slightly as compared to OSGCM. The runoff timing/amount deficiency in OSGCM is comparatively larger.

The ISM for 1988-1987 show a large difference in the Great Plains (Fig. 3c). The 1988 summer (especially June) was much drier than normal. Unfortunately, NSGCM does not improve the simulation of precipitation compared to OSGCM. No interannual signal is shown in any of the GCM simulations compared to the offline for sensible heat or evaporation. The ISM difference in both OSGCM and NSGCM nearly vanish after a month, after which the deficiencies of the forecast mask the results. The EFxpts simulations show no interannual trends of soil wetness throughout the summer, as expected.

\subsection{June and JJA differences in evaporation and precipitation}

Globally, the NSGCM 1988-1987 JJA evaporation and precipitation is shown in Fig. 4a, while the OSGCM differences are shown in Fig. 4b. The 1987 Indian drought is captured by the GCM simulations, but the 1988 Great Plains drought is clearly not. However, the difference in precipitation is quite large over the equatorial Americas and Sahel in Africa in response to changing SSTs over the central $\mathrm{Pa}$ cific Ocean. The NSGCM simulations have a larger 1988-1987 difference of evaporation and precipitation than OSGCM over northern India. Higher ISM in central Asia extending into the Himalayas 

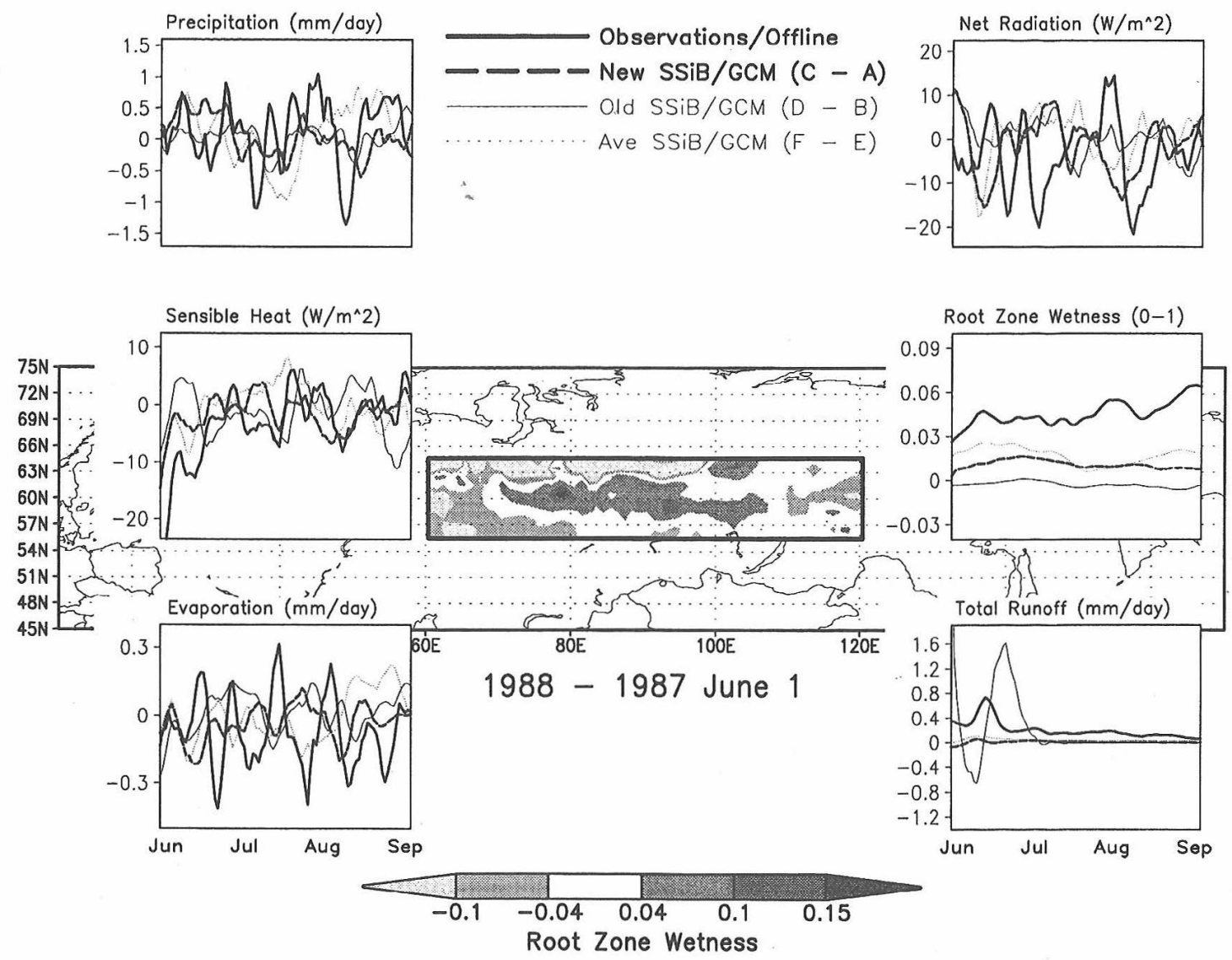

Fig. 3b. Same as Fig. 3a, only for Russia (55-65N; 60-120E).

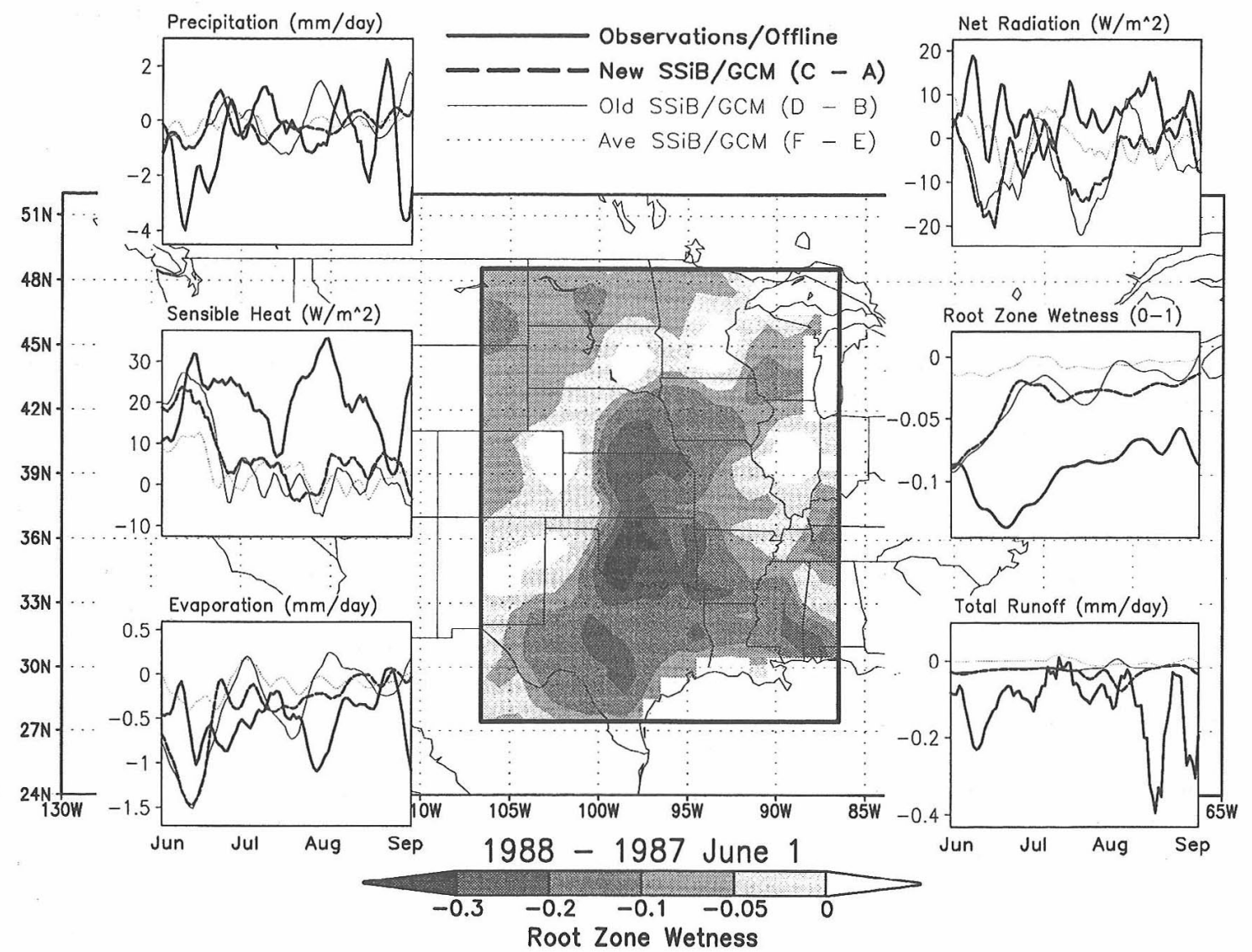

Fig. 3c. Same as Fig. 3a, only for the U.S. (27-49N; 107-86W). 


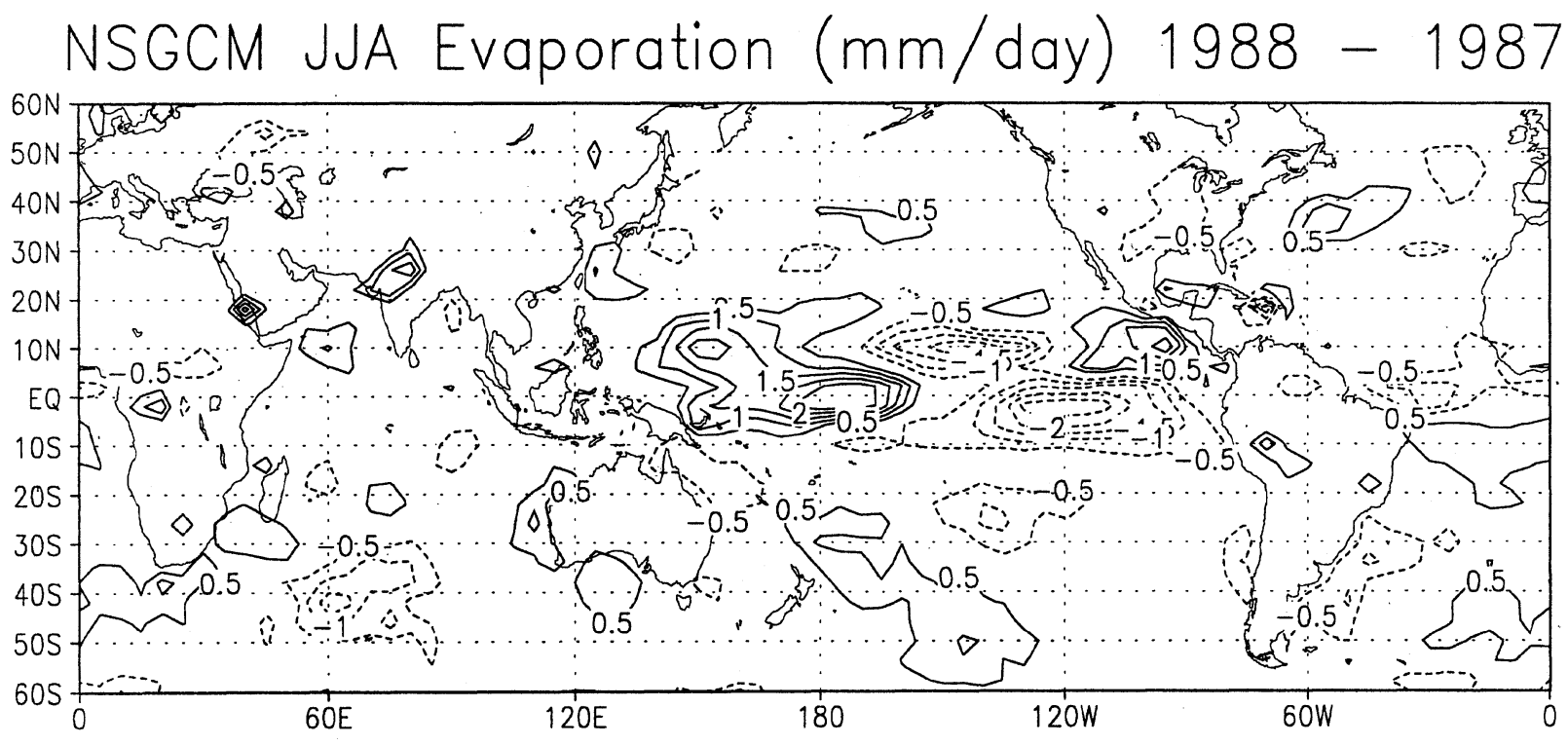

\section{NSGCM JJA Precipitation (mm/day) 1988 - 1987}

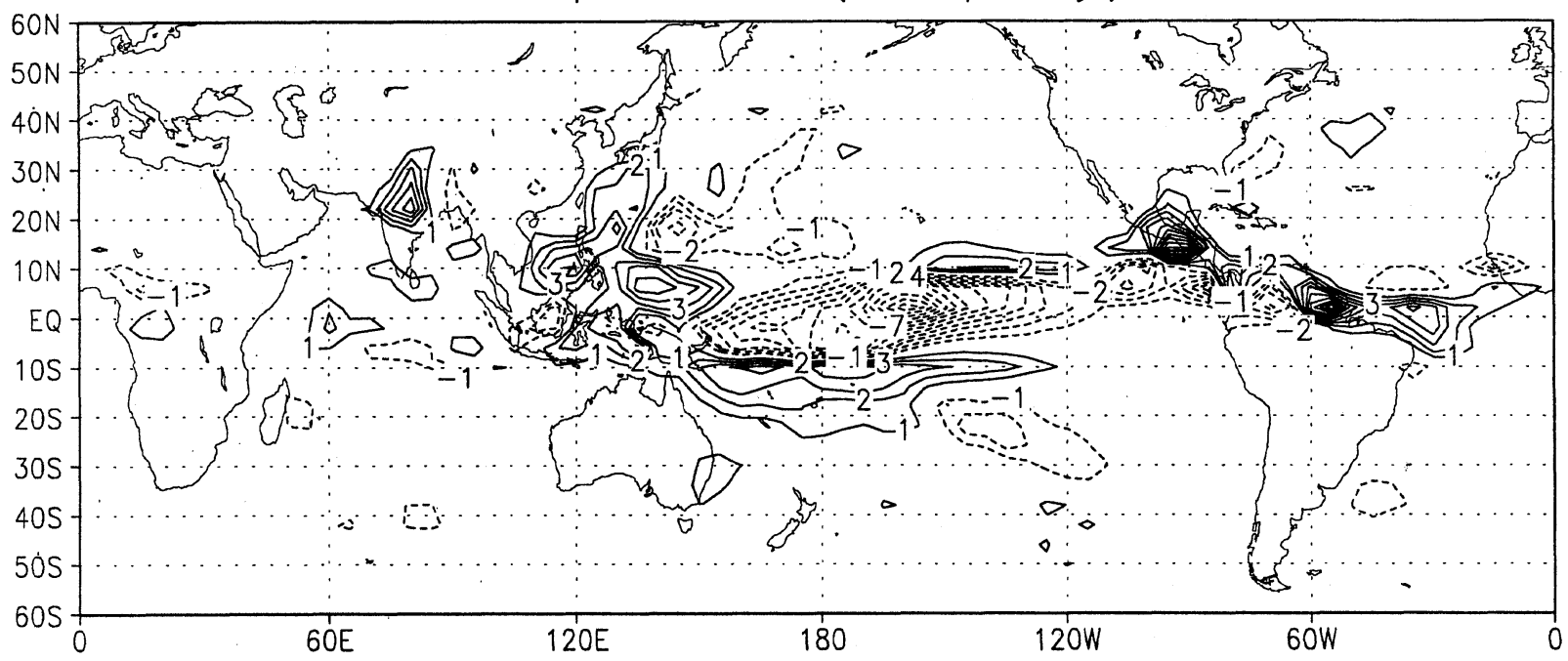

Fig. 4a. 1988-1987 JJA Difference in Evaporation (top) and Precipitation (bottom) in NSGCM (Simulations $\mathrm{C}-\mathrm{A}$ ). Units in $\mathrm{mm-day}{ }^{-1}$.

has increased the interannual signal. Matsuyama and Masuda (1998) found that the variations of soil moisture in this region play a small but contributing effect to the Indian summer monsoon precipitation.

The differences in evaporation and precipitation over North America are shown in Figs. 5a and 5b. NSGCM and OSGCM both produced less evaporation in the central plains in 1988, similar to that produced by the offline, while in the Pacific northwest more evaporation is found, as in the offline. The GCM-produced precipitation only does a fair job in the June interannual difference. Generally drier in 1988 is predicted, as observed, around the Great Lakes and Canada; generally wetter in northwest
Canada and in the Pacific northwest is also similar to the observations. However, the GCM produces a wetter 1998 across the southern states, which was not observed. This trend also is shown near Texas, extending partially into the central plains.

Examining similar figures for the entire JJA period (Figs. 5c and 5d), shows that even the modest successes in June have been nearly eliminated by the end of the summer. The NSGCM produces slightly less evaporation in 1988 compared to 1987 than OSGCM, but for both NSGCM and OSGCM, the 1988-1987 precipitation difference is too small in the central U.S. However, NSGCM does have a slightly better difference in precipitation, as com- 


\section{OSGCM JJA Evaporation (mm/day) 1988 - 1987}

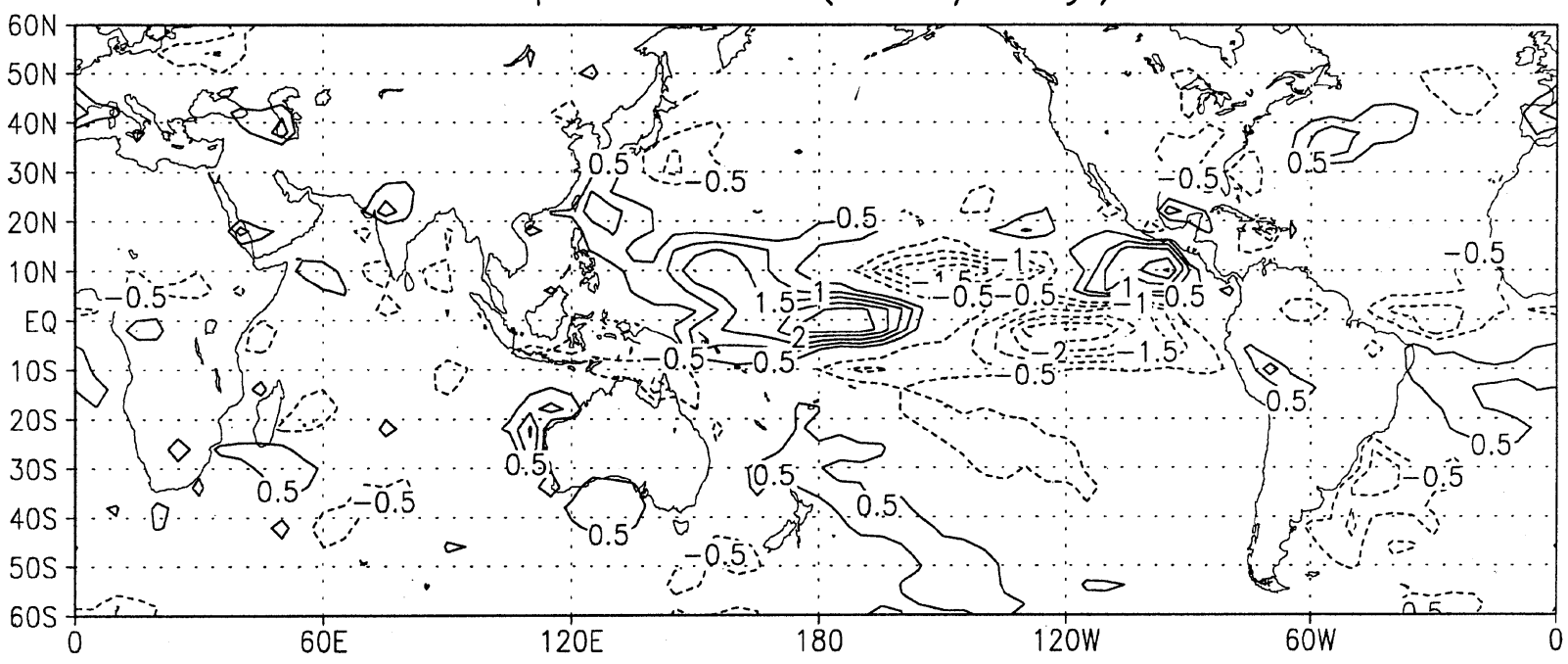

\section{OSGCM JJA Precipitation (mm/day) 1988 - 1987}

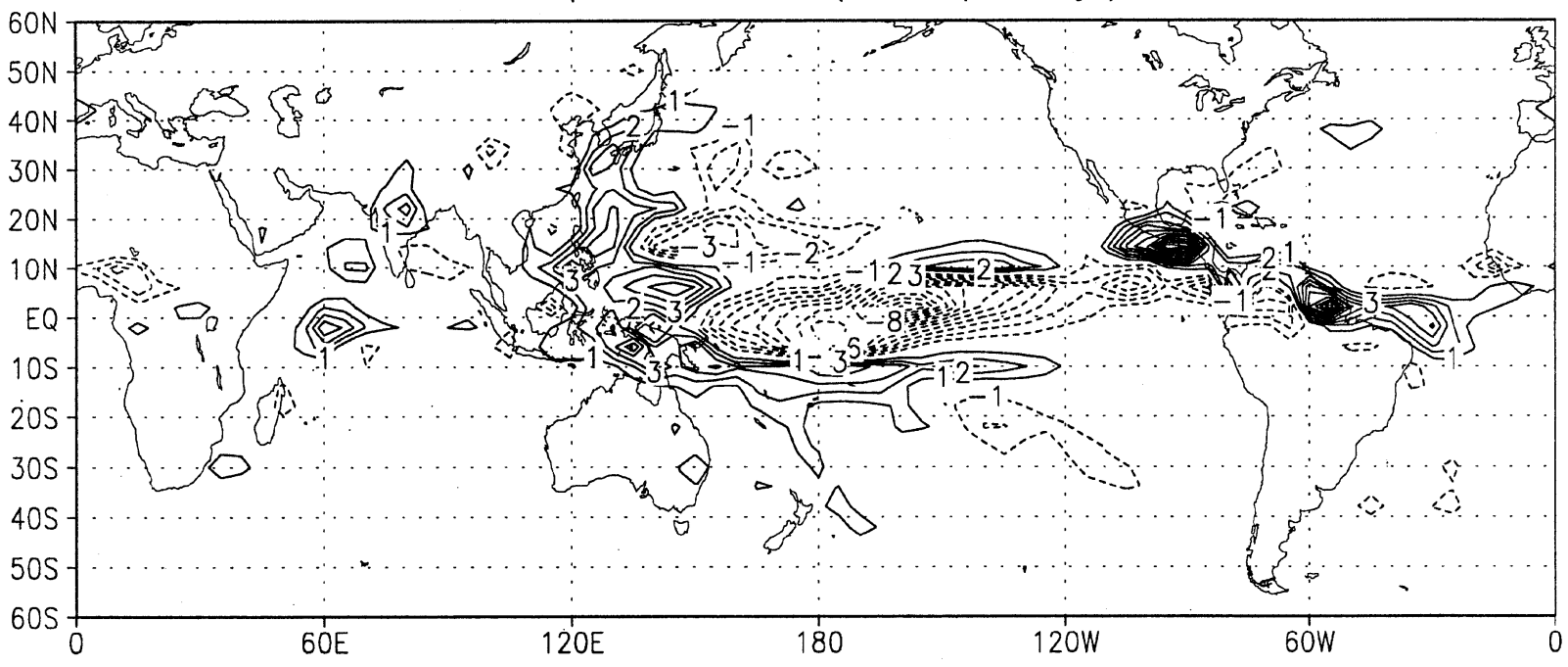

Fig. 4b. 1988-1987 JJA Difference in Evaporation (top) and Precipitation (bottom) in OSGCM (Simulations $\mathrm{D}-\mathrm{B})$. Units in $\mathrm{mm}-\mathrm{day}^{-1}$.

pared to the observations than OSGCM in both northern Canada and in the U.S. around $90 \mathrm{~W}$.

\subsection{Statistical significance}

The statistical significance of the new model is shown in Fig. 6. The fields are the student's ttest values of the runs in the ensemble. Greater than $\pm 95 \%$ significance is shaded. The top two panels show the effect of the new snow model on evaporation and precipitation. These panels confirm that the effect of the new snow model is conclusively to increase evaporation and precipitation in mid-to-high latitude regions with significant spring snow-melt. These are spectacular improvements. The bottom two panels show the 1988-1987 differ- ences in precipitation for both the NSGCM and OSGCM experiments. The main features, naturally, are the interannual differences associated with El Nino centered in the equatorial Pacific. Over the central U.S., the NSGCM produced a stronger 1988 drought than did the OSGCM. In northern India, NSGCM also produced a stronger interannual difference in precipitation. These are useful, though only marginal, improvements to the simulation.

\section{Summary and conclusion}

Improved ISM makes an improvement in the prediction of surface fluxes, precipitation, and hydrology in the GCM. Comparison of the old snow model in $\mathrm{SSiB}$ with the new snow model in SSiB shows 

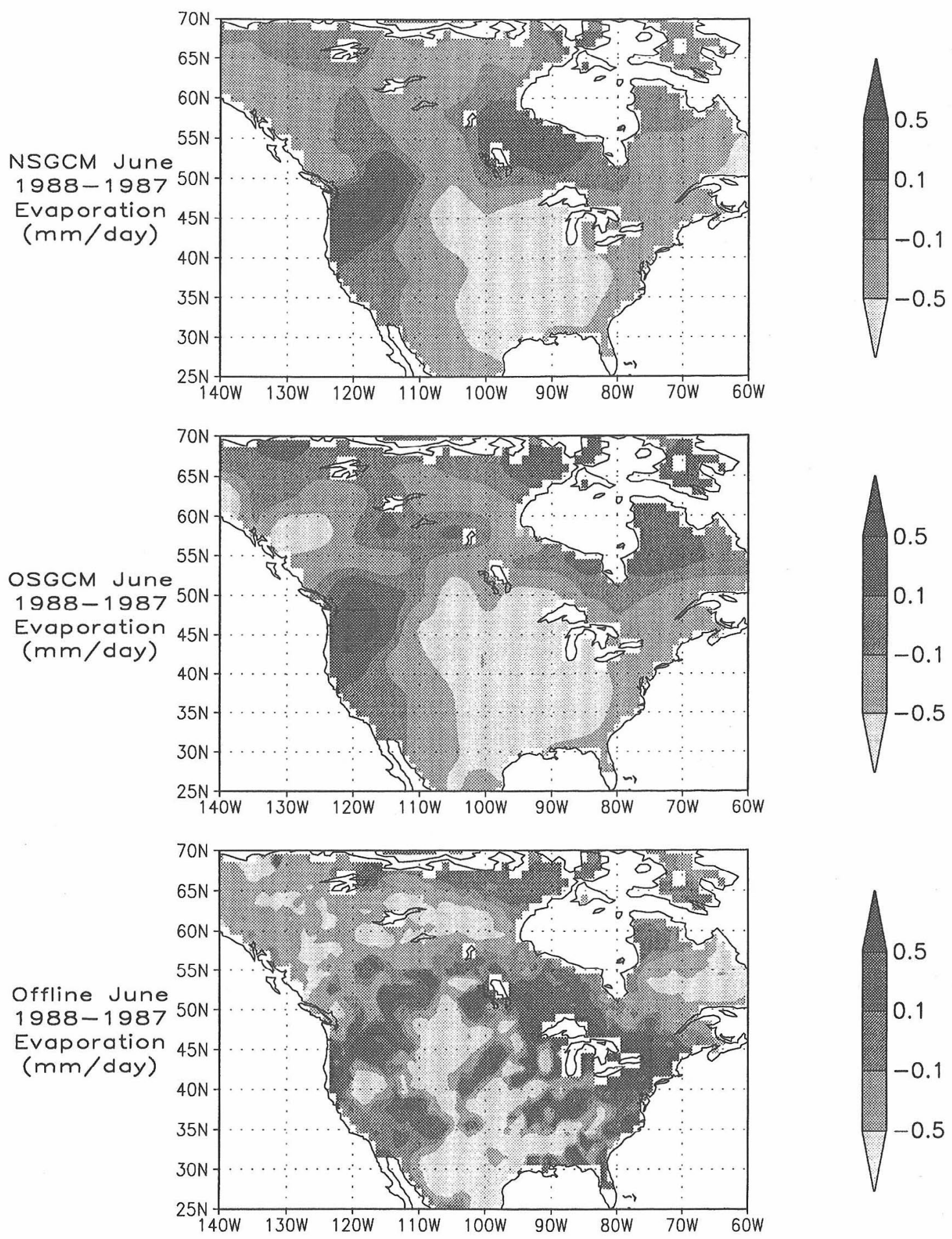

Fig. 5a. 1988-1987 Difference in June Evaporation for NSGCM (Simulations C-A, top), OSGCM (Simulations D-B, middle), and offline $\mathrm{SSiB}$ (bottom). Units in mm-day ${ }^{-1}$.

that higher soil moisture is simulated with the new snow model. The wetter ISM leads to larger evapotranspiration in the snow-melt regions; correspondingly, sensible heat flux is smaller. While the fluxes are not verifiable with observations, comparison of precipitation produced by the GCM shows that the new snow model in SSiB with the improved ISM significantly improves the simulation in areas with significant snow-melt. Furthermore, simulated soil moisture and runoff are more realistic, as compared to both offline SSiB simulation and observations.

Two significant events over land of the 1987-1988 circulation and precipitation differences were the 1988 drought over the U.S. and the 1987 drought 

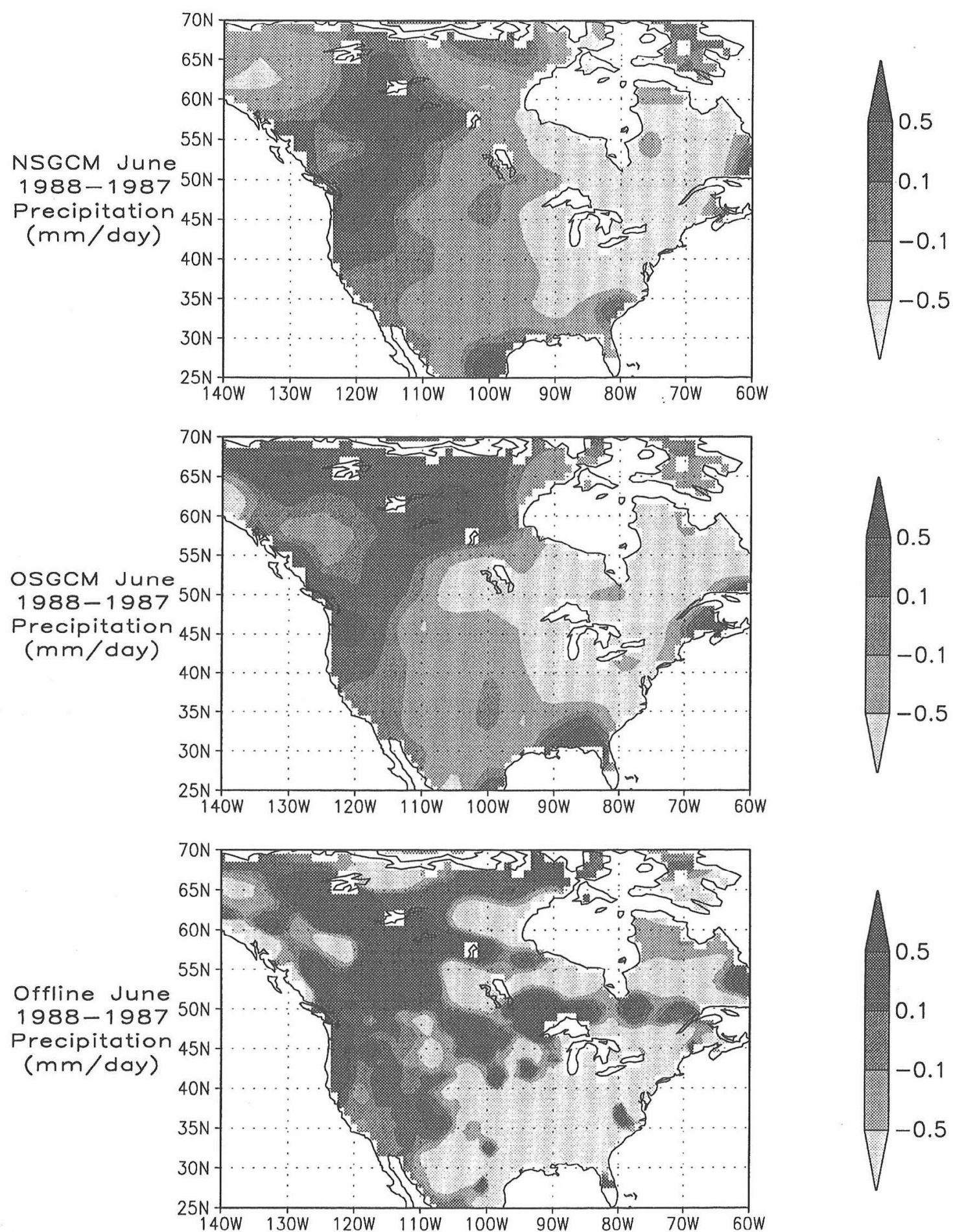

Fig. 5b. 1988-1987 Difference in June Precipitation for NSGCM (Simulations C-A, top), OSGCM (Simulations $\mathrm{D}-\mathrm{B}$, middle), and offline $\mathrm{SSiB}$ (observed, bottom). Units in $\mathrm{mm}^{-d_{a y}{ }^{-1}}$.

over India. The soil moisture deficiency over the U.S. was produced in the offline analysis, and was accompanied by larger sensible heat and reduced evapotranspiration. The GCM simulations, however, started off in the right direction, but were unable to maintain the drought beyond one month. Accordingly, the June evapotranspiration and pre- cipitation have some resemblance to the offline or observations, but this advantage is lost by the end of the summer. The main failing of the simulations is in maintaining a drought circulation with a sea level pressure high over the northern plains in 1988. The observed circulation had strong subsidence over the Great Plains, which the model is not able to main- 

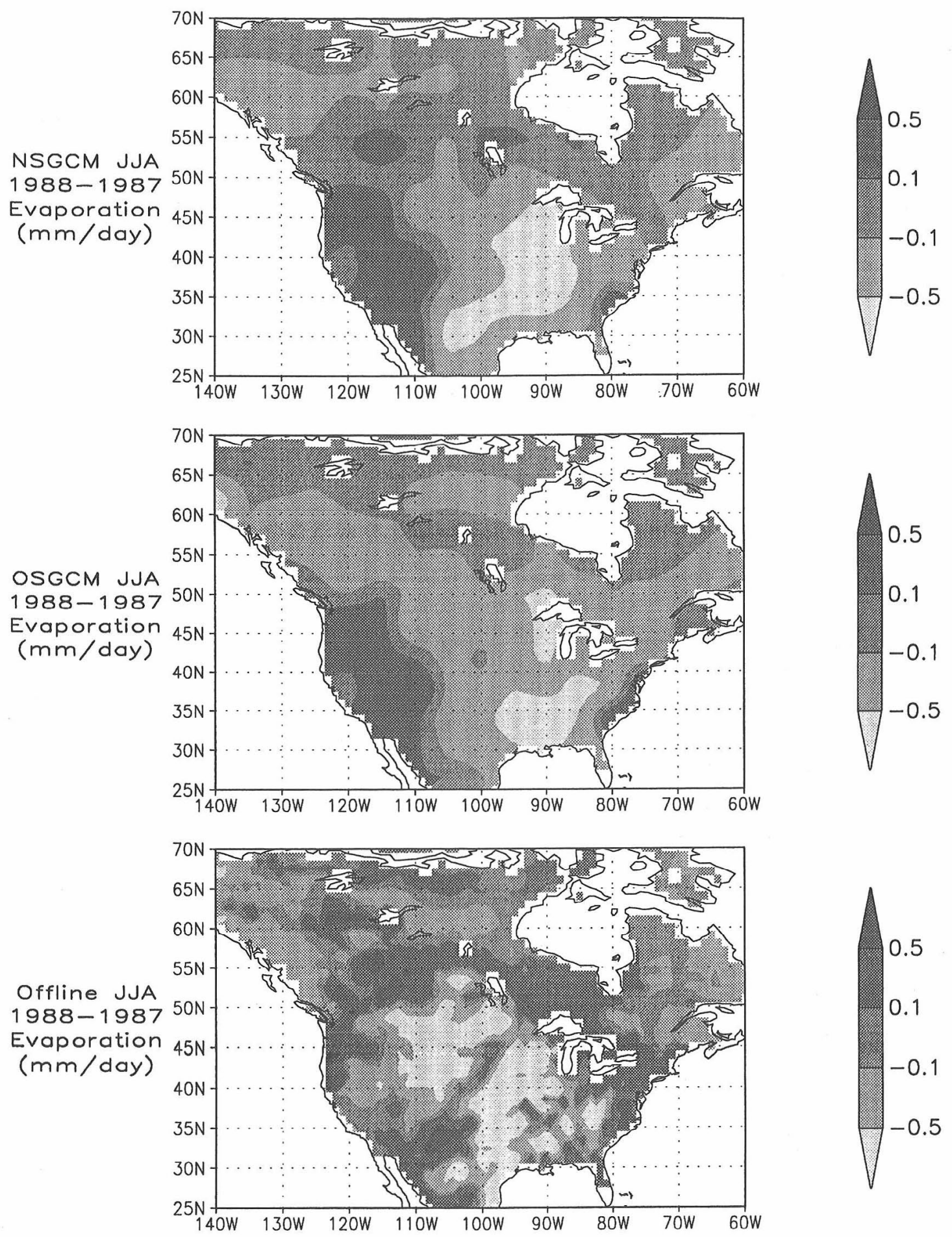

Fig. 5c. 1988-1987 Difference in JJA Evaporation for NSGCM (Simulations C-A, top), OSGCM (Simulations D-B, middle), and offline SSiB (bottom). Units in mm-day ${ }^{-1}$.

tain. In the end, a small gain is noted in the new $\mathrm{SSiB}$ GCM as compared to the old. However, the correct simulation of the circulation in this region may have more significant causes than its feedback effect on ISM.

The Indian subcontinent had a 100-year drought in 1987. The ISM conditions on 1 June for this region are very dry for both years. The drought is a response to SST anomalies related to El Niño and La Niña, and possibly to other anomalies in the Eurasian region. Both the new SSiB GCM and old SSiB GCM simulations are able to capture this quite well. The new SSiB GCM produced a stronger anomaly, as a response of changing ISM. 

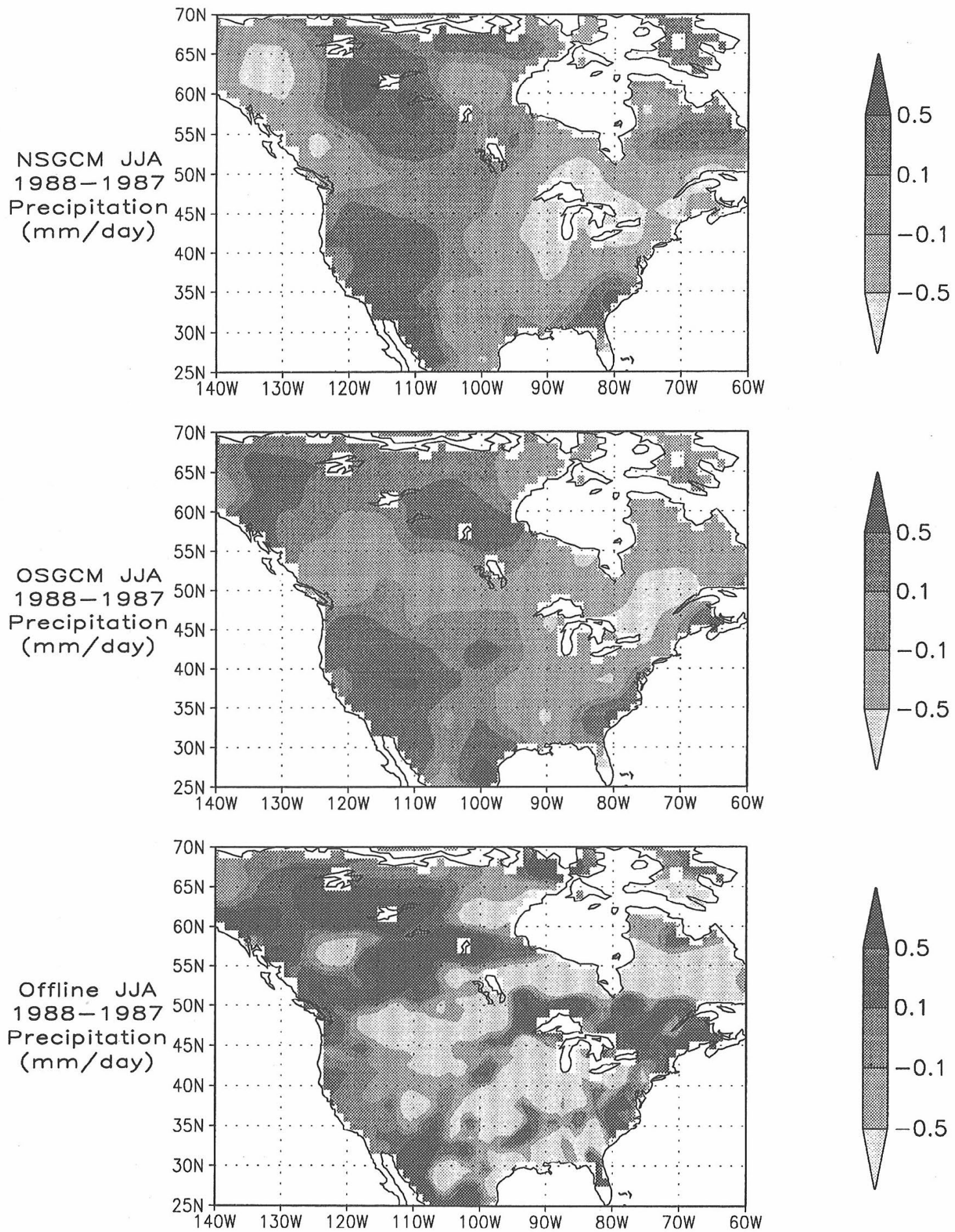

Fig. 5d. 1988-1987 Difference in JJA Precipitation for NSGCM (Simulations C-A, top), OSGCM (Simulations $\mathrm{D}-\mathrm{B}$, middle), and offline $\mathrm{SSiB}$ (observed, bottom). Units in mm-day ${ }^{-1}$.

Accordingly, it can be inferred that this precipitation anomaly is mostly SST-forced, as had been widely known, but ISM in the region may have an influence.

\section{Acknowledgments}

The authors thank Kenneth Bergman of NASA
Headquarters for supporting this research. Thanks are also extended to Taikan Oki for assisting with runoff comparisons to observations, and to Alan Robock's group at the University of Maryland for providing soil moisture observations, as well as to other members of the GSWP group. The suggestions of two anonymous reviewers helped to improve 

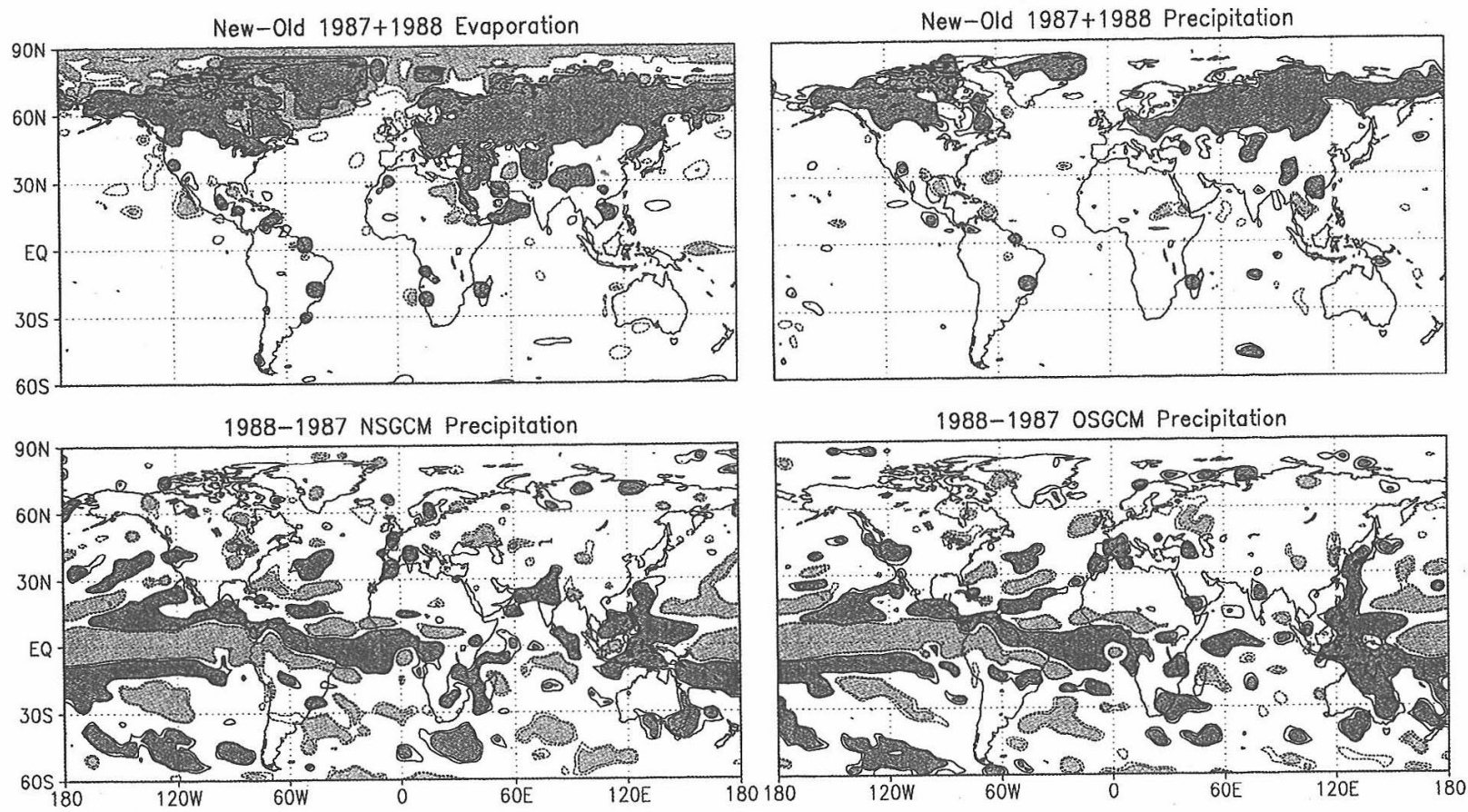

Fig. 6. Student's t-test value of the effect of NSGCM on evaporation and precipitation (top), and a comparison of NSGCM and OSGCM 1988-1987 precipitation differences (bottom). Shaded areas indicated $\pm 95 \%$ statistical significance. Dashed lines and light shadings are negative, solid lines and dark shadings are positive.

this paper.

\section{References}

Atlas, R., N. Wolfson and J. Terry, 1993: The effect of SST and soil moisture anomalies on GLA model simulations of the 1988 United States summer drought. J. Climate, 6, 2034-2048.

Beljaars, A.C.M., P. Viterbo, M.J. Miller and A.K. Betts, 1996: The anomalous rainfall over the United States During July 1993: Sensitivity to land surface parametrization and soil moisture anomalies. Mon. Wea. Rev., 124, 362-383.

Betts, A.K., F. Chen, K.E. Mitchell and Z.I. Janjić, 1997: Assessment of the land surface and boundary layer models in two operational versions of the NCEP Eta model using FIFE data. Mon. Wea. Rev., 125, 2896-2916.

Budyko, M.I., 1956: Teplovoi Balans Zemnol Poverkhnosti. Gidrometeoizdat; Heat Balance of the Earth's Surface, translated by N.A. Stepanove., U.S. Weather Bur., 1958. MGA 8.5-20, 13E-286, 11B-25. $259 \mathrm{pp}$.

Dirmeyer, P.A., 1999: Assessing GCM sensitivity to soil wetness using GSWP. J. Meteor. Soc. Japan, 77, 367-385.

Garratt, J.R., 1993: Sensitivity of climate simulations to land-surface and atmospheric boundary-layer treatments - a review. J. Climate, 6(3), 419-449.

Gates, W.L., 1992: AMIP, The Atmospheric Model Intercomparison Project. Bull. Amer. Meteor. Soc., 73, 1962-1970.
Hollinger, S.E. and S.A. Isard, 1994: A soil moisture climatology of Illinois. J. Climate, 7, 822-833.

Huffman, G.J., R.F. Adler, P. Arkin, A. Chang, R. Ferraro, A. Gruber, J. Janowiak, A. McNab, B. Rudolf and U. Schneider, 1997: The global precipitation climatology project (GPCP) combined precipitation datasets. Bull. Amer. Meteor. Soc., 78, 5-20.

Lau, K.-M., J.H. Kim and Y.C. Sud, 1996: Intercomparison of hydrologic processes in AMIP GCMs. Bull. Amer. Meteor. Soc., 77(10), 2209-2227.

Lau, K.-M. and S. Yang, 1996: The Asian monsoon and predictability of the tropical ocean-atmosphere system. Quart. J. Roy. Meteor. Soc., 122, 945-957.

Manabe, S., 1969: The atmospheric circulation and the hydrology of the earth's surface. Mon. Wea. Rev., 97, 739-774.

Matsuyama, H. and K. Masuda, 1998: Seasonal/Interannual variations of soil moisture in the former USSR and its relationship to Indian summer monsoon rainfall. J. Climate, 11(4), 652-658.

Meeson, B.W., F.E. Corprew, J.M.P. McManus, D.M. Myers, J.W. Closs, K.-J. Sun, D.J. Sunday and P.J. Sellers, 1995. ISLSCP Initiative I Global Data Sets for Land-Atmosphere Models, 1987-1988. Volumes 1-5. Published on CD by NASA (USA_NASA_GDAAC_ISLSCP_ 001 USA_NASA_GDAAC_ISLSCP_005).

Mintz, Y., 1984: The sensitivity of numerically simulated climates to land-surface conditions. In $\mathrm{J}$. Houghton (Ed.), The Global Climate, pp. 79-105. Cambridge University Press. 
Mintz, Y. and Y. Serafini, 1984: Global fields of normal monthly soil moisture as derived from observed precipitation and estimated potential evapotranspiration. Part V. 173575, Final Scirntific Report under NASA Grant No. NAS5-26. Department of Meteorology, University of Maryland College Park, MD 20742. 182pp.

Mintz, Y. and G.K. Walker, 1993: Global fields of soil moisture and land surface evapotranspiration derived from observed precipitation and surface air temperature. J. Appl. Meteor., 32, 1305-1334.

Miyakoda, K., J. Sirutis and R.F. Strickler, 1979: Cumulative results of extended forecast experiment. Part II: Model performance for summer cases. Mon. Wea. Rev., 107, 395-420.

Mocko, D.M. and Y.C. Sud, 1998: Comparison of a landsurface model $(\mathrm{SSiB})$ to three parameterizations of evapotranspiration - a study based on ISLSCP Initiative I data. Earth Interactions, 2, 40 pp.

Robock. A., K.Y. Vinnikov, C.A. Schlosser, N.A. Speranskaya and Y. Xue, 1995: Use of midlatitude soil moisture and meteorological observations to validate soil moisture simulations with biosphere and bucket models. J. Climate, 8, 15-35.

Schneider, U., 1993: The GPCC quality-control system for gauge-measured precipitation data. WMO/TDNo. 558, A5-A7, Report of the GEWEX Workshop Analysis Methods of Precipitation on a Global Scale, [Available from World Meteorological Organization, P.O. Box 2300, CH-1211 Geneva 2, Switzerland].

Sellers, P.J., B.W. Meeson, J. Closs, J. Collatz, F. Corprew, D. Dazlich, F.G. Hall, Y. Kerr, R. Koster, S. Los, K. Mitchell, J. McManus, D. Myers, K.-J. Sun and P. Try, 1995. An overview of the ISLSCP Initiative I Global Data Sets. On: ISLSCP Initiative I - Global Data Sets for Land-Atmosphere Models, 1987-1988. Volumes 1-5. Published on CD by NASA. Volume 1: USA_NASA_GDAAC_ISLSCP_001, OVERVIEW.DOC.

Sud, Y.C. and M.J. Fennessy, 1984: A numerical study on the influence of evaporation in semi-arid regions on the July circulation. J. Climatol., 4, 383-398.
Sud, Y.C. and D.M. Mocko, 1999: New snow-physics to complement SSiB. Part I: Design and evaluation with ISLSCP Initiative I datasets. J. Meteor. Soc Japan, 77, 335-348.

Sud, Y.C. and A. Molod, 1988: The roles of dry convection, cloud-radiation feedback processes and the influence of recent improvements in the parametrization of convection in the GLA GCM. Mon. Wea. Rev., 116(11), 2366-2387.

Sud, Y.C. and W.E. Smith, 1985: Influence of local surface processes on the Indian monsoon - a numerical study. J. Clim. Appl. Meteor., 29, 185-210.

Sud, Y.C. and G.K. Walker, 1999: Microphysics of clouds with the Relaxed Arakawa-Schubert Scheme (McRAS). Part I: Design and Evaluation with 6-ATE Phase III data. J. Atmos. Sci, in press.

Takacs, L.L., A. Molod and T. Wang, 1994: Documentation of the Goddard Earth Observing System (GEOS) General Circulation Model - Version 1. 104606, NASA Technical Memorandum. Volume 1, 100pp.

Vinnikov, K.Y. and I.B. Yeserkepova, 1991: Soil moisture: Empirical data and model results. J. Climate, 4, 66-79.

Xie, P. and P.A. Arkin, 1995: An intercomparison of gauge observations and satellite estimates of monthly precipitation. J. Appl. Meteor., 34, 1143-1160.

Xue, Y., P.J. Sellers, J.L. Kinter and J. Shukla, 1991: A simplified biosphere model for global climate studies. J. Climate, 4, 345-364.

Xue, Y., P.J. Sellers, F.J. Zeng and C.A. Schlosser, 1997: Comments on "Use of midlatitude soil moisture and meteorological observations to validate soil moisture simulations with biosphere and bucket models". $J$. Climate, 10, 374-376.

Yang, R., M.J. Fennessy and J. Shukla, 1994: The influence of initial soil wetness on medium-range surface weather forecasts. Mon. Wea. Rev., 122(3), 471485.

Zhou, J., Y.C. Sud and K.-M. Lau, 1996: Impact of orographically induced gravitywave drag in the GLA GCM. Quart. J. Roy. Meteor. Soc., 122, 903-927. 
$\mathrm{SSiB}$ を改良した新雪モデル

II: GEOS II GCMによる土壌水分初期值化と地表フラックス・降水・水文への効果

\section{D.M. Mocko • G.K. Walker • Y.C. Sud}

(Laboratory for Atomosheres, NASA/Goddard Space Flight Center)

GSWP ISLSCP Initiative Iデータで強制した SSiB モデルをより現実的な雪の物理過程と融雪浸透過 程を導入して改良した。新モデルを GSWPデータで再度積分した。新 SSiB は顕著な融雪のある地域にお いて、より湿って暖かい土壤をシミュレートし、より現実的な融雪時期と流出をもたらした。このシミュ レーションを使って GEOS II GCM の地面温度・土䁃水分・積雪を初期值化し、1987 年と 1988 年 $6 \sim 8$ 月のアンサンブルランを行った。それぞれのアンサンブルは 5 月 29 日から 6 月 3 日の ECMWF 再解析を 初期值とする 6 例である。

旧 SSiB GCM に比べて、新水文過程を含む新 SSiB GCM ではカナダとロシアの中・高緯度帯の降水 予測が顕著に改善された。蒸発散、土壤水分、流出も、新 SSiB GCM は旧 SSiB GCM に比べて良くなっ た。さらに、北部インドの降水量の 1988 年と 1987 年の差も新 SSiB GCM でより強調された。米国では、 旧 SSiB GCM では 1988 年の干ばつ状態のシミュレーションに失敗したが、新 SSiB GCM では少し良く なった。これは 1988 年と 1987 年の差でも明らかである。この領域では初期条件の影響は約 1 月で失わ れ、その後非現実的な循環になる。 